\title{
Quantifying the Impact of 20-Year Flood Frequency on Land Cover Change Type
}

\author{
Francois G. F. Smith ${ }^{1}$, David J. Alexander ${ }^{2, *}$ \\ ${ }^{1}$ Senior Imagery Scientist, Radiant Solutions \\ ${ }^{2}$ Chief Geospatial Scientist | Flood APEX Lead, First Responders Group, US Department of Homeland Security \\ *Corresponding author: david.alexander1@hq.dhs.gov
}

\begin{abstract}
Flooding is the most common and destructive natural disaster in the United States. Ninety percent of all disasters in the US involve flooding, with impacts that cascade across the entire landscape. The primary objective of this study is to understand the impact of flooding on the landscape. One way to determine this is to observe the number of times a unit area of land is flooded and intersect that information with quantified changes in the landscape. The information for this analysis is derived from a complex workflow with inputs from large amounts of Landsat satellite imagery (more than 300 images) and multiple dates of land cover data from the USGS NLCD. The acquired NLCD data were used to generate from-to bivariate land cover change classes. A bivariate dataset was created for 5 date pair epochs. These classes were then used as zonal boundaries within which statistical variables were generated based on the flood frequency layer. By analyzing this information, we characterized what classes changed to what other classes given different frequencies of flooding. The area of interest for this study consists of one path row or footprint of a Landsat image on the border of Louisiana, Texas, and Arkansas near the city of Shreveport, Louisiana. This study area is known to have frequent flooding and a diverse landscape. During our analysis, we discovered that land cover changes in this study area more often occurred within areas that had flooded, rather than areas that had not flooded. Barren land cover change is clearly associated with flooding. Agricultural land changing to barren suggested that frequent flooding may cause arable land to not be as productive. When Barren land changes to vegetated cover and when Water changes to Barren, there is a strong likelihood that the change was due to flooding. Interestingly Urban land cover changes intersected with flood frequency regardless of the ratio. Over 2600 ha of Urban were built within the areas that have previously flooded. Some of the from-to change identified in this analysis was due to classification error, however this was minimized due to USGS's approach to land cover classification update, whereby only areas of change are classified. The results of this analysis are very useful for identifying where land cover change areas exist, their extent, and the likelihood they are associated with flood activity. This has implications and applications to flood plain management and community land use planning. The results of this study showed there is a relationship between some land cover change types and areas that frequently flood.
\end{abstract}

Keywords: remote sensing, GIS, land cover change, flooding, Landsat, bivariate analysis, floodplain management

Cite This Article: Francois G. F. Smith, and David J. Alexander, "Quantifying the Impact of 20-Year Flood Frequency on Land Cover Change Type.” American Journal of Civil Engineering and Architecture, vol. 6, no. 1 (2018): 13-23. doi: 10.12691/ajcea-6-1-2.

\section{Introduction}

Flooding is the most common and destructive natural disaster in the United States. Ninety percent of all disasters in the US involve flooding with impacts that cascade across the entire landscape. While advances have been made in weather forecasting and watershed modeling to predict the future; it is still difficult to measure or characterize and assess the broad impact of flood inundation on the ground over a large area with historical context. In other words, there is a gap in our understanding of how land management is influenced by flooding over time. However, flooding can be quantified over time and space if you have access to satellite imagery at regular intervals.
The Landsat mission, having acquired data since 1972, and since 1982 at 30m resolution, affords researchers the ability to compile a backward looking dataset of change that can be combined with forward looking models to project future conditions.

The fusion of remote sensing and GIS has proven to be a valuable tool in land management and planning, enabling empirical observation of periodic changes in the surface of the earth for large areas over time $[1,2,3]$. This is especially important for long term community resilience planning and disaster risk mitigation, when it is necessary to understand past, present, and future conditions. This paper utilizes advances in satellite remote sensing and geospatial science to quantify the effect of frequent flooding on land cover over time using Landsat earthobserving data. More specifically, it explores how often a 
selected study area floods, and what impact the frequency of flood events has on that landscape over a 20-year period using multi-date Landsat imagery and United States Geological Survey (USGS) National Land Cover Dataset (NLCD) data for the same area.

The contributions of this type of application has implications for public policy, community planning, and the practices of floodplain, storm water, and emergency management. It will produce an invaluable empirical (quantifiable) dataset that can be used to inform community mitigation and planning efforts - to improve our understanding of flood risk, and flood prone areas, and as an aid for prioritizing flood studies. With improved longitudinal understanding at the pixel level of flood risk, more empirical conclusions can be made on the impact of local land-use and economic development plans and infrastructure capacity. This understanding will also help us to:

1. Better understand the impact of frequent flooding on the landscape,

2. More logically predict what will happen to the landscape and how land is used in areas that flood multiple times, and

3. Ascertain how land cover will change over time as a response to climate change, as changes in weather patterns occur, flooding will likely occur in different frequencies and in new areas

\section{Study Objective and Design}

The primary objective of this study is to understand the impact of flooding on the landscape. One way to determine this is to observe the number of times a unit area of land is flooded and intersect that information with quantified changes in the landscape. If an area floods only once or twice in a decade, does the land cover change in a similar fashion as if it floods 100 times in a decade? Is there a correlation between how much an area floods and what type of land cover change occurs? Do these patterns of change occur consistently across decades? And finally are there specific types of land cover that are more prone to flooding?

In this study we intersected flood frequency data derived from satellite imagery with bivariate (from-to class) land cover change, which is also derived from satellite imagery. Five different epochs were tested:

- 2011 to 1992

- 2011 to 2001

- 2011 to 2006

- 2006 to 2001

- 2001 to 1992.

Flood frequency and land cover change were calculated for each of these date ranges. These two variables were intersected using a zonal majority function and tables were produced for analysis.

\section{Data and Methods}

Two datasets were acquired for this study, Landsat imagery and USGS NLCD land cover data. The 33+ year archive of Landsat satellite imagery is the only source of systematic regular observations which may have captured a flood event. Approximately 20 years of Landsat imagery (ranging from 1984 to 2011) were compiled for the same scene footprint for the study area near Shreveport, Louisiana. Landsat 4-8 imagery ranging in dates of acquisition from 1984 to 2011 was downloaded and processed from the EROS Data Center. Over 300 scenes were downloaded, all of which cover the same footprint. A filter of $<20 \%$ clouds was implemented. All images were corrected to account for astronomical and atmospheric factors that typically produce error in radiance values [4]. Clouds and cloud shadows were removed from all Landsat scenes. The images were then individually classified to produce binary water masks using a sophisticated water extraction algorithm. The flood extents were determined by direct detection of standing water and by inference from vegetation/soil stress due to soil saturation and observation post flood. The spatial extent of flooded areas was entirely based on satellite imagery observations. Flood frequency for each pixel was generated using the flood extent observations. The water masks were then stacked and the frequency of water inundation per pixel was calculated (0-100\%). The stack of water masks were examined to determine the number of times each pixel had been inundated. Then the images were stacked according to the study time periods described in section 2 above. Frequencies were calculated for each of these date ranges. In order to analyze the impacts of flooding on land cover and land use, remote sensing change detection techniques were applied to the Landsat and NLCD data time series at 30-meters resolution. The process workflow is shown in Figure 1.

NLCD layers were also downloaded from the USGS. USGS NLCD land cover data was obtained for the same area for the target dates, 1992, 2001, 2006, and 2011. The NLCD is "a classification scheme based primarily on Landsat data along with ancillary data sources, such as topography, census and agricultural statistics, soil characteristics, wetlands, and other land cover maps" [5]. The NLCD provides researchers a consistent land cover classification scheme for the conterminous US at the same 30-m resolution as Landsat imagery. NLCD employs an approximately 20-class classification scheme (Figure 2).

The acquired NLCD data were used to generate from-to bivariate land cover change classes. A bivariate dataset was created for each data pair epoch listed above in section 2. A bivariate layer has a unique value for each possible from-to class permutation. Therefore there are $n^{2}$ number of bivariate classes where $\mathrm{n}=$ the number of classes in the original classification scheme. Our NLCD dataset contains 20 classes, therefore our bivariate layers contained 400 classes of from-to change. These classes were then used as zonal boundaries within which statistical variables were generated based on the flood frequency layer. By analyzing this information, we characterized what classes changed to what other classes given different frequencies of flooding. We also examined other statistics such as flood variability to understand its impact on land cover change. Finally we list the frequency of flooding for each of the NLCD categories in the study area. 


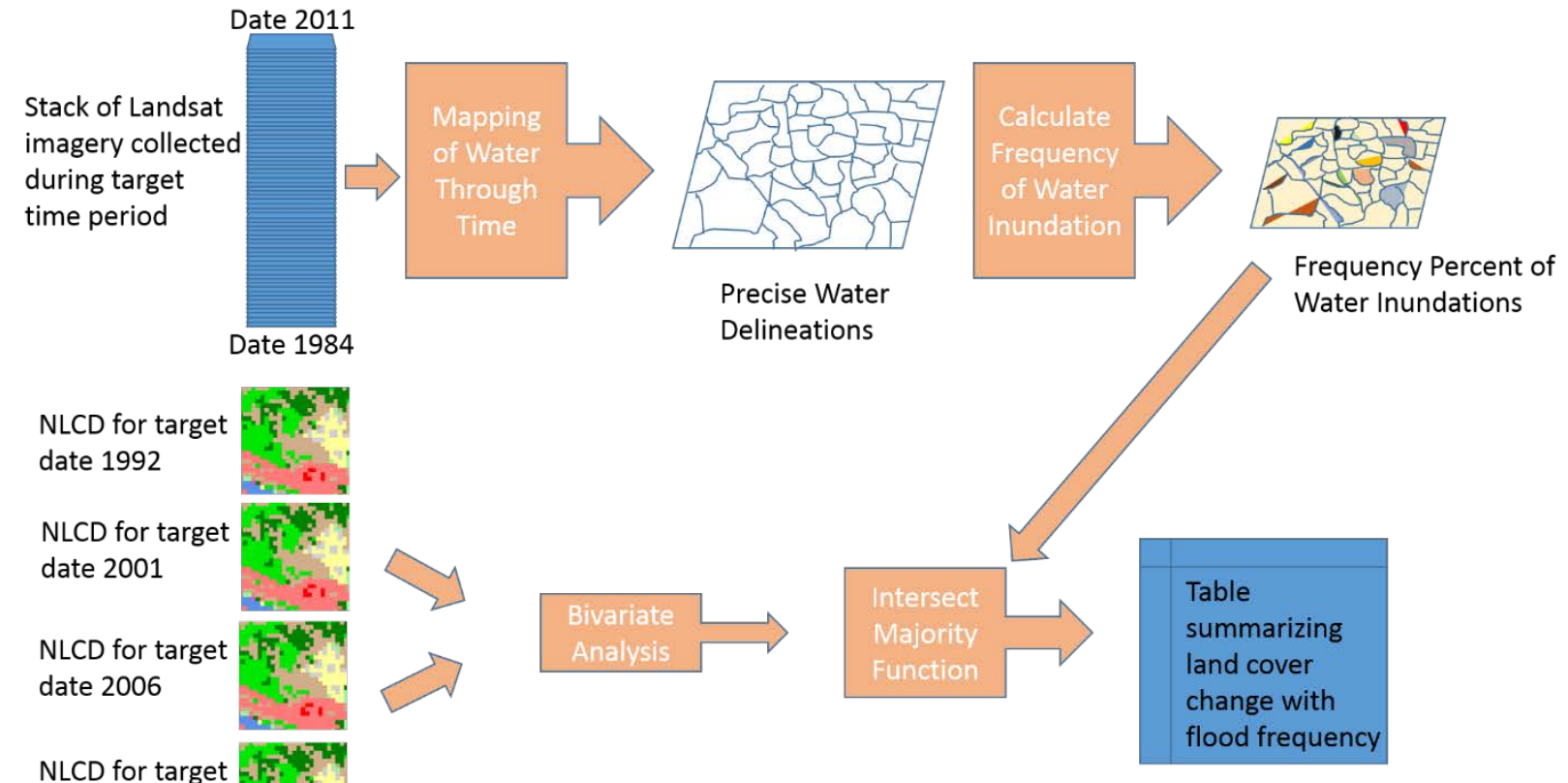

Figure 1. Data Processing Workflow

\begin{tabular}{|l|}
\hline NLCD Land Cover Classification Legend \\
11 Open Water \\
12 Perennial Ice/ Snow \\
21 Developed, Open Space \\
22 Developed, Low Intensity \\
23 Developed, Medium Intensity \\
24 Developed, High Intensity \\
31 Barren Land (Rock/Sand/Clay) \\
41 Deciduous Forest \\
42 Evergreen Forest \\
43 Mixed Forest \\
51 Dwarf Scrub* \\
52 Shrub/Scrub \\
71 Grassland/Herbaceous \\
72 Sedge/Herbaceous* \\
73 Lichens* \\
74 Moss* \\
81 Pasture/Hay \\
82 Cultivated Crops \\
90 Woody Wetlands \\
95 Emergent Herbaceous Wetlands \\
\hline$\square$ \\
\hline \\
\hline \\
\hline
\end{tabular}

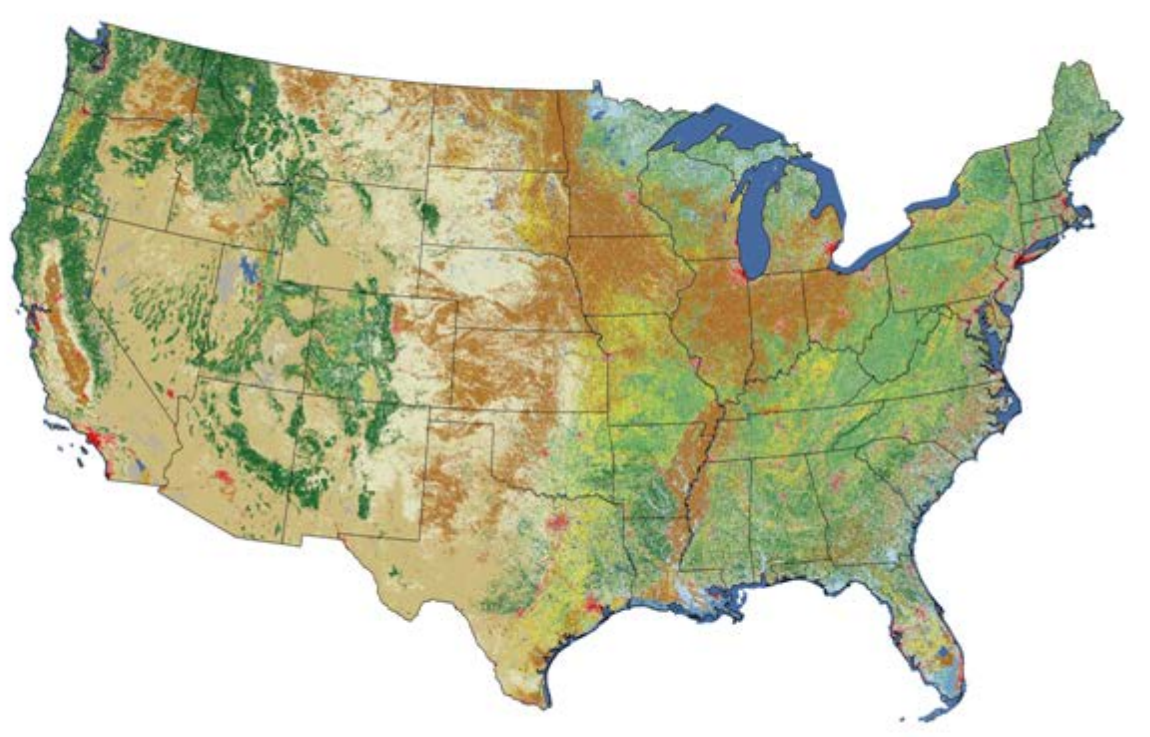

Figure 2. NLCD: National Land Cover Dataset created for 4 epochs, by USGS

\section{Study Area}

The area of interest for this study consists of one path row or footprint of a Landsat image on the border of Louisiana, Texas, and Arkansas near the city of Shreveport, Louisiana. (Figure 3). The area covers a little over 2.5 million hectares and is a fairly diverse landscape. It also contains the Red River which has flooded many times over the last 30 years. The Red River is the second largest river basin in the southern Great plains, and its watershed covers 65,590 square miles $\left(169,900 \mathrm{~km}^{2}\right)$ [6]. (Figure 4) The sister cities of
Shreveport and Bossier City lie on either bank of the Red River after it crosses south into Louisiana. Even farther downstream, the Red River connects to the Mississippi river by the Old River control structure, where it becomes the Atchafalaya River before flowing into the Gulf of Mexico [6]. The Old River control structure was completed by the US Army Corps of Engineers in 1963 to regulate the flow of water between the Mississippi river and the Atchafalaya River [7]. (Figure 5.). During this downstream journey, the Red River watershed transitions from pine forests and agricultural land into effusive marshland [7]. 


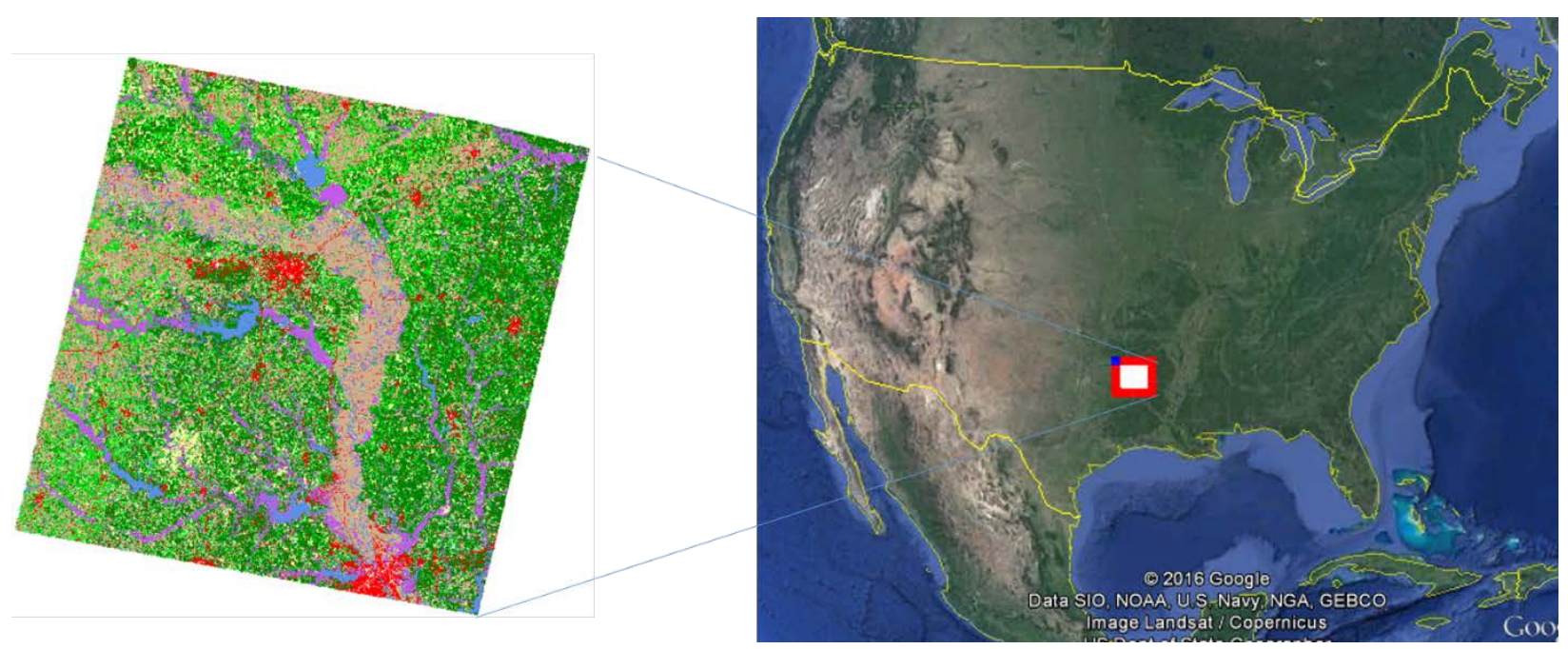

Figure 3. Study Area: Red River near Shreveport, La

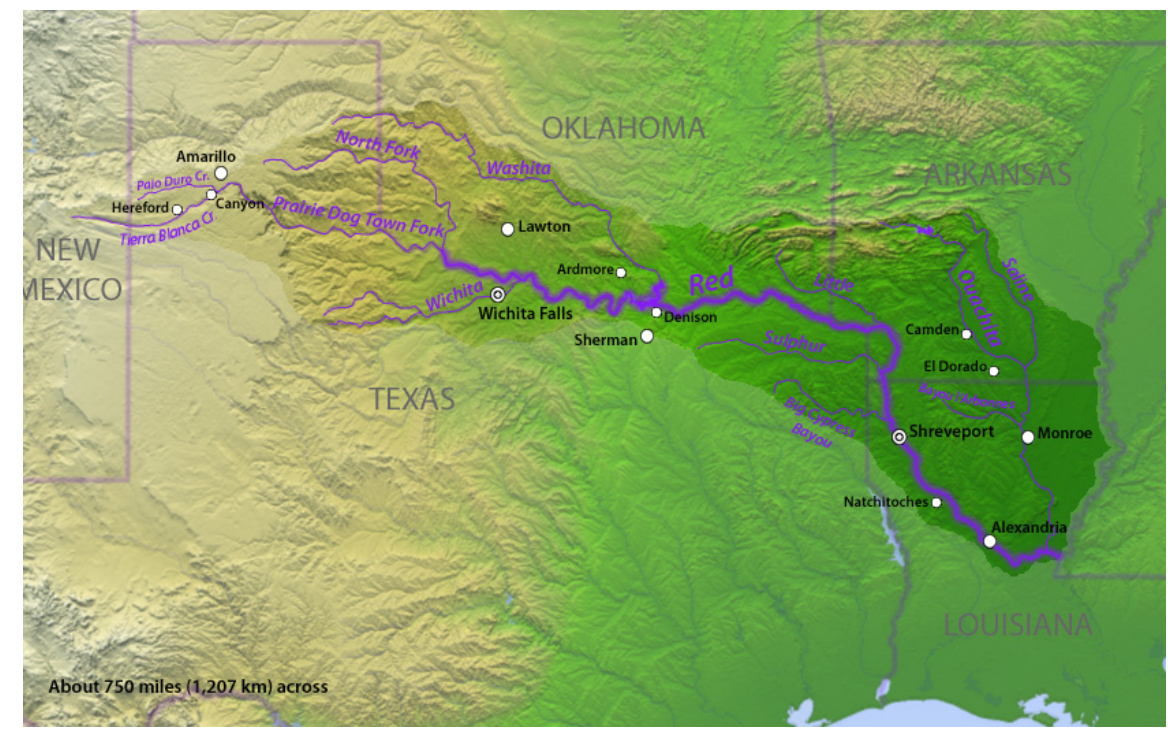

Figure 4. Red River Watershed

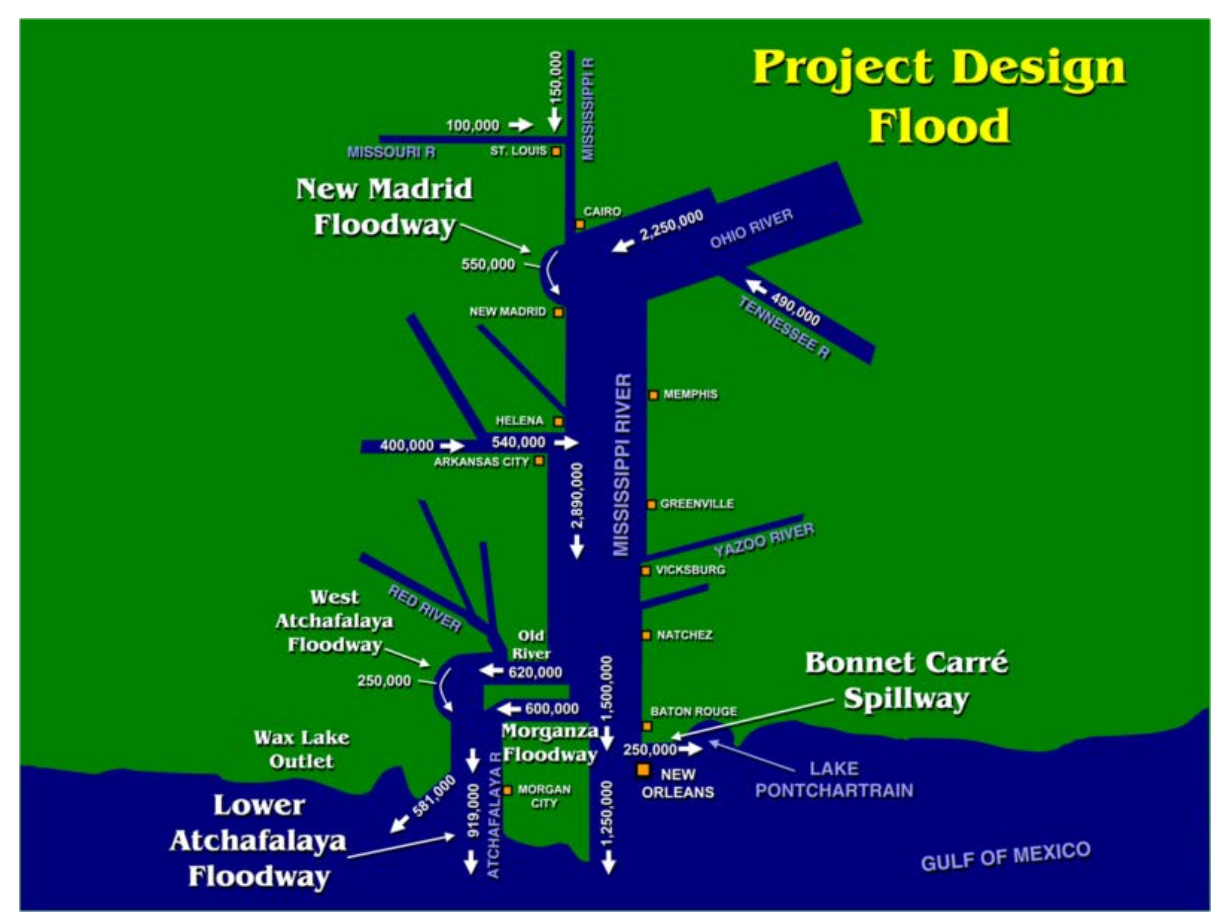

Figure 5. Old River Control Structure (Courtesy of US ACE 2014) 
The Shreveport area has a humid subtropical climate with average normal annual precipitation over 51 inches $(1.3 \mathrm{~m})$, and monthly totals ranging from 5 inches (130 $\mathrm{mm}$ ) in June to 3 inches (76 mm) in August. During the spring and summer months, the region is plagued by severe thunderstorms with heavy rain, hail, damaging winds and tornadoes. (NWS 2017). While historically prone to riverine flooding, the study area has experienced an increasing number of floods related to heavy precipitation rainfall events or flash floods likely attributable to land-use changes and urbanization. The Shreveport-Bossier Metro region is the commercial and cultural center where the three states of Texas, Arkansas, and Louisiana meet [8]. According to the US Census, in 2010, the population in the Shreveport metro region exceeded 411,000, a $323 \%$ increase from when it was established in 1950 (pop. 126,206).

\section{Analysis}

In Figure 6, you can see a subset of the study area that is focused on a portion of the Red River in the north. This figure depicts the percent flood frequency layer overlaid on a raw Landsat image from the time series. The color ramp bar on the right side shows the continuum of frequency of water calls in the stack of imagery. Red means a pixel was only called water once in the entire stack and magenta means the pixel was called water in every scene in the stack of images. A "permanent" water feature such as a lake is depicted as magenta. All of the colors in between represent pixels that are intermittently inundated with water a various number of times. The maximum extent of a one-time major flood would appear as red. Figure 7 shows another portion of the study area near Millwood Lake. In this figure, Millwood Lake is depicted as magenta. Several areas in the left quadrant of the image are red suggesting one-time flood events. Figure 8 shows the land cover change for the same portion of Red River in the north of the study area depicted in Figure 6. Similarly, Figure 9 shows the land cover change for the portion of the study area near Millwood Lake depicted in Figure 7.

The zonal majority intersection process was performed on each of the 5 ranges of dates of the datasets described in section 2. The process resulted in a series of tables (Table 1 - Table 5). The first column shows the from-to bivariate change class. The second column shows the ratio of flood to non-flood pixels. This is the number of pixels that changed within areas that flooded divided by number of pixels that did not flood. This ratio represents how many times we observed this from-to change type within flood areas as opposed to outside observed flood areas. If this ratio is higher than a value of 1 , then it occurred more times within areas that flooded than areas that did not flood. The higher the value, the more related to flooding that change type is. The third column shows the number of hectares covered by that bivariate class, and the fourth column is the same area but represented in pixels. The following columns are all percents of observed water frequency. These tables represent up to $15 \%$ flood frequency because that is the range where the more catastrophic flooding occurs, but the analysis includes up to $50 \%$. Beyond $50 \%$ we are more likely dealing with seasonal water inundations rather than floods.

First we looked for a higher ratio of flood pixels to nonflood pixels in the table and if they covered a significant number of hectares, a red box was placed around these classes in the tables. This is the number of pixels that changed within areas that flooded divided by the number of pixels that did not flood. For this study we are looking only at pixels where a change type occurred more times in areas that flooded than in areas that did not. The higher the ratio (in the second column), the more likely the change type is flood induced, we are defining flood induced change as changes that happened more often within flooded areas than outside of flooded areas. For this analysis, frequently flooded areas were defined as areas that are observed as flooded more than once in the 20-year dataset (1984 to 2011). Inundations occurring in more than fifty percent of the observations were considered "permanent" water (Inundation occurring > 50\%). Inundations occurring in greater than one percent and less than or equal to fifty percent of the observations were considered "intermittent" or flooded water (Inundation occurring $>1 \%$ and $<=50 \%$ ). Tables for the five date pairs were summarized to show only results where the ratio was greater than one (ratio $(\mathrm{R})>1$ ). The resulting tables (five sets) were then analyzed and interpreted.

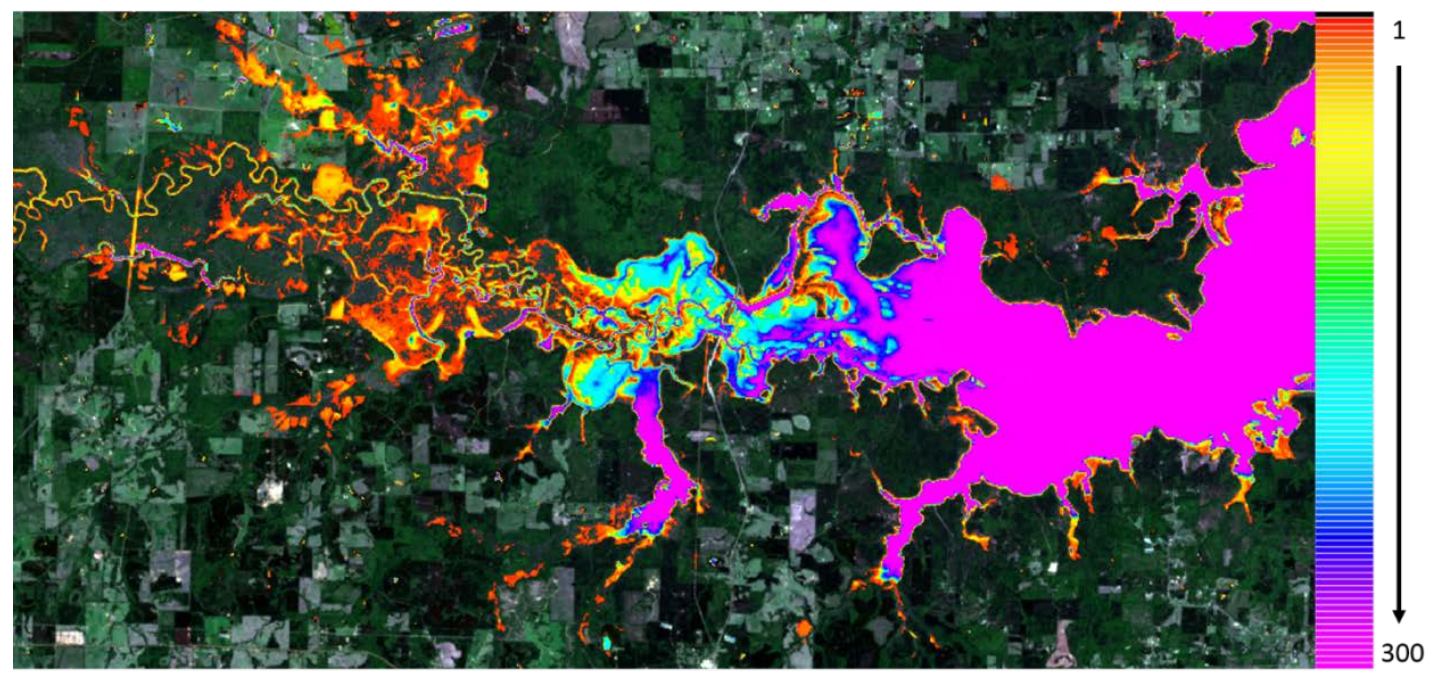

Figure 6. Example of Flood Inundation Layer for the Study area in north portion of the Red River 


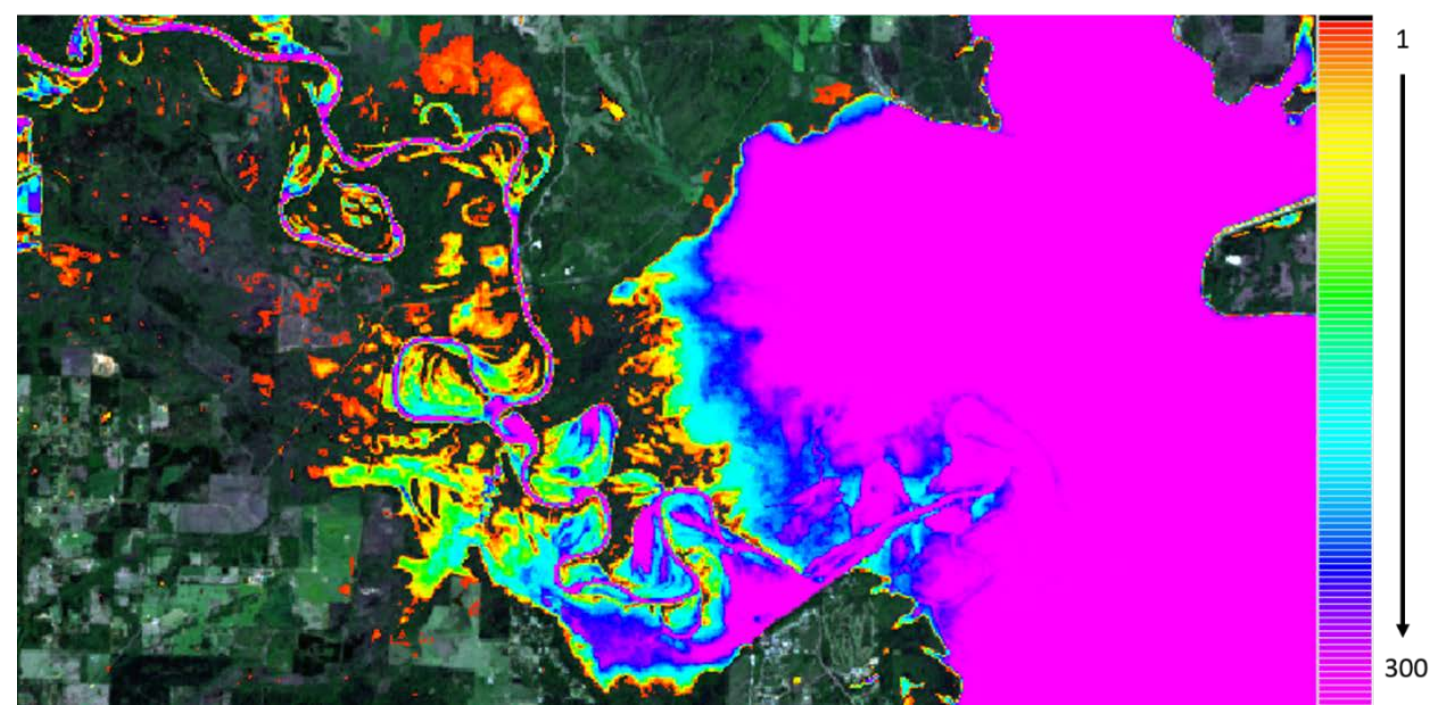

Figure 7. Example of Flood Inundation Layer for the study area near Millwood Lake

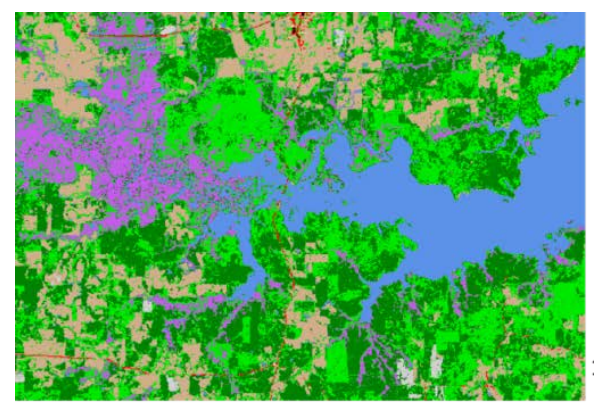

19922006
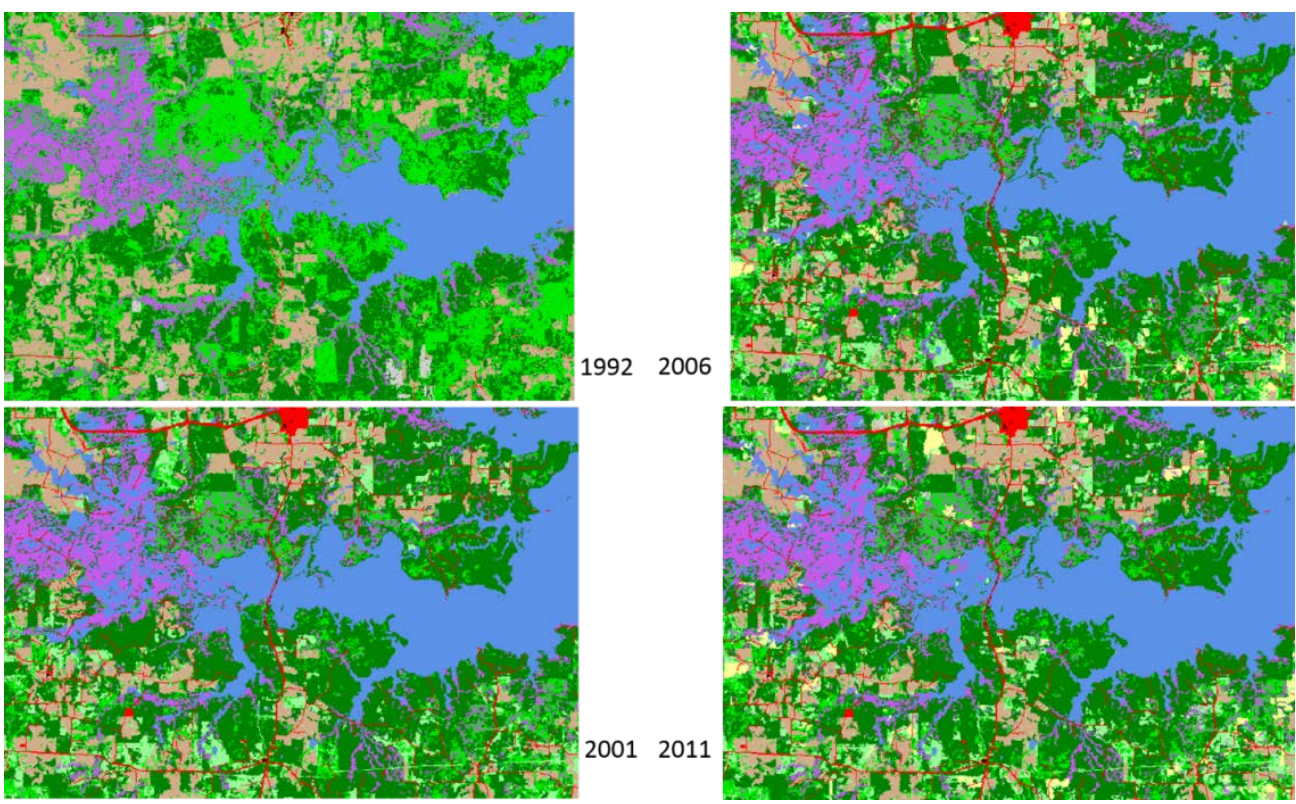

Figure 8. Land cover change for the Study area in north portion of the Red River

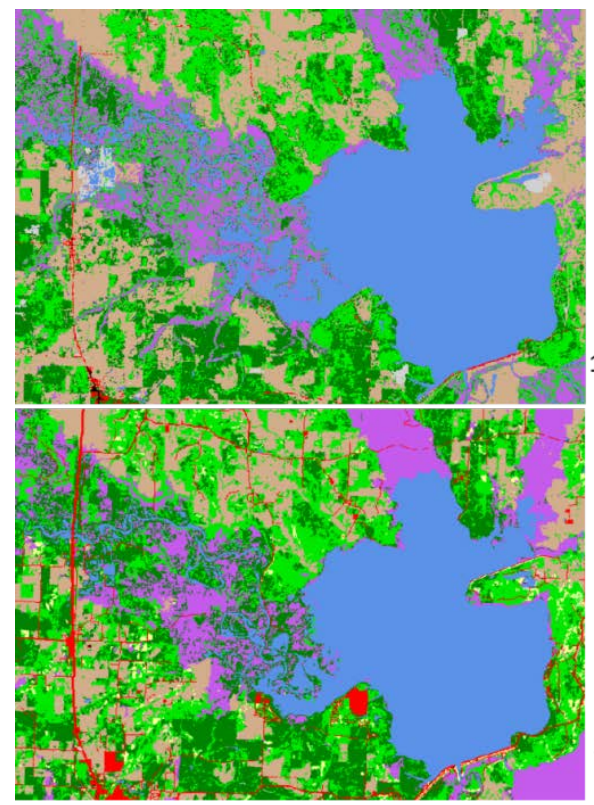

19922006

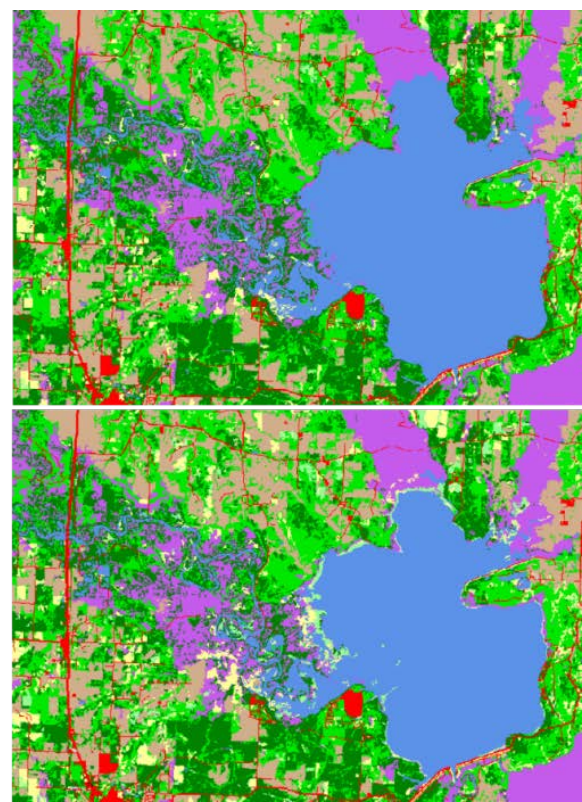

Figure 9. Land cover change for the Study area near Millwood Lake 
Table 1. 1992-2001 Flood Frequency Impact on Land Cover, Summarized Table

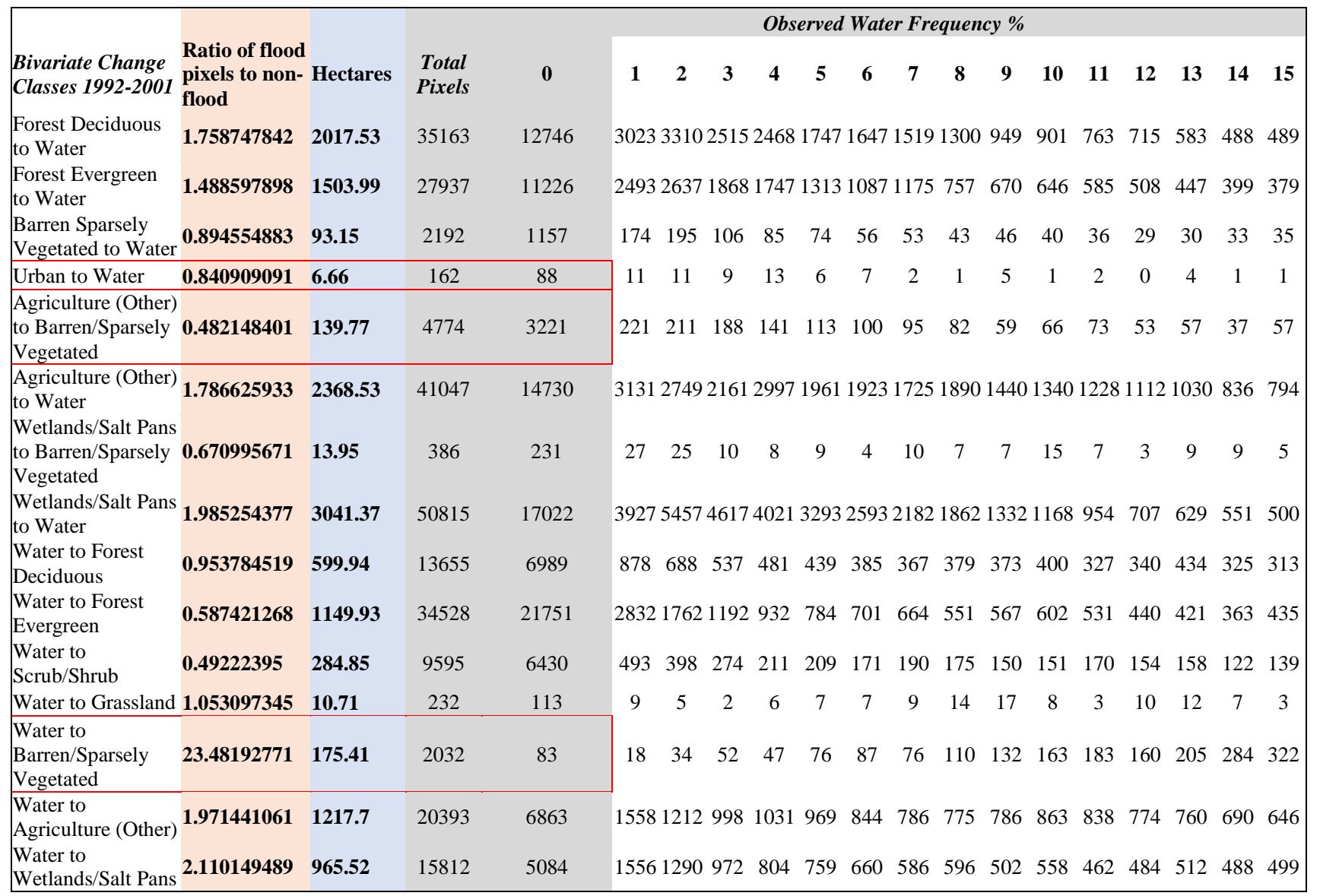

Table 2. 2001-2006 Flood Frequency Impact on Land Cover, Summarized Table

\begin{tabular}{|c|c|c|c|c|c|c|c|c|c|c|c|c|c|c|c|c|c|c|c|}
\hline \multirow[b]{2}{*}{$\begin{array}{l}\text { Bivariate Change Classes 2001- } \\
2006\end{array}$} & \multirow[b]{2}{*}{$\begin{array}{l}\text { Ratio of flood } \\
\text { pixels to non- } \\
\text { flood }\end{array}$} & \multirow[b]{2}{*}{ Hectares } & \multirow[b]{2}{*}{$\begin{array}{l}\text { Total } \\
\text { Pixels }\end{array}$} & \multicolumn{16}{|c|}{ Observed Water Frequency \% } \\
\hline & & & & $\mathbf{0}$ & 1 & 2 & 3 & 4 & 5 & 6 & 7 & 8 & 9 & 10 & 11 & 12 & 13 & 14 & 15 \\
\hline Forest Deciduous to Water & 1.911242604 & 87.21 & 1476 & 507 & 0 & 87 & 24 & 32 & 39 & 15 & 17 & 23 & 25 & 8 & 19 & 27 & 16 & 11 & 22 \\
\hline Forest Evergreen to Water & 1.96043956 & 80.28 & 1347 & 455 & 0 & 92 & 33 & 27 & 43 & 25 & 19 & 32 & 21 & 17 & 15 & 20 & 7 & 21 & 23 \\
\hline Scrub/Shrub to Water & 3.44295302 & 92.34 & 1324 & 298 & 0 & 78 & 36 & 28 & 32 & 15 & 11 & 26 & 18 & 13 & 24 & 13 & 20 & 20 & 21 \\
\hline Grassland to Water & 5.166666667 & 2.79 & 37 & 6 & 0 & 4 & 0 & 5 & 1 & 0 & 1 & 0 & 0 & 0 & 0 & 0 & 1 & 0 & 1 \\
\hline $\begin{array}{l}\text { Barren Sparsely Vegetated to } \\
\text { Forest Deciduous }\end{array}$ & 2.615384615 & 9.18 & 141 & 39 & 0 & 8 & 5 & 1 & 2 & 0 & 0 & 0 & 0 & 1 & 1 & 0 & 1 & 1 & 1 \\
\hline $\begin{array}{l}\text { Barren Sparsely Vegetated to } \\
\text { Forest Evergreen }\end{array}$ & 1.157772622 & 44.91 & 930 & 431 & 0 & 47 & 1 & 30 & 30 & 8 & 17 & 19 & 17 & 16 & 25 & 15 & 19 & 16 & 16 \\
\hline $\begin{array}{l}\text { Barren Sparsely Vegetated to } \\
\text { Scrub/Shrub }\end{array}$ & 4.923076923 & 28.8 & 385 & 65 & 0 & 22 & 0 & 18 & 11 & 1 & 5 & 4 & 4 & 11 & 19 & 8 & 13 & 8 & 8 \\
\hline $\begin{array}{l}\text { Barren Sparsely Vegetated to } \\
\text { Grassland }\end{array}$ & 10.43589744 & 36.63 & 446 & 39 & 0 & 17 & 4 & 24 & 11 & 5 & 12 & 2 & 2 & 7 & 5 & 9 & 10 & 5 & 10 \\
\hline $\begin{array}{l}\text { Barren Sparsely Vegetated to } \\
\text { Agriculture (Other) }\end{array}$ & 1.11627907 & 17.28 & 364 & 172 & 0 & 33 & 2 & 8 & 8 & 1 & 8 & 3 & 0 & 2 & 5 & 2 & 6 & 4 & 2 \\
\hline $\begin{array}{l}\text { Barren Sparsely Vegetated to } \\
\text { Wetlands/Salt Pans }\end{array}$ & 30.44444444 & 49.32 & 566 & 18 & 0 & 36 & 8 & 2 & 14 & 7 & 11 & 31 & 30 & 17 & 11 & 14 & 13 & 15 & 8 \\
\hline $\begin{array}{l}\text { Barren Sparsely Vegetated to } \\
\text { Water }\end{array}$ & 17.40677966 & 92.43 & 1086 & 59 & 0 & 24 & 0 & 19 & 13 & 2 & 17 & 5 & 5 & 17 & 8 & 13 & 6 & 5 & 7 \\
\hline Agriculture (Other) to Water & 6.577540107 & 442.8 & 5668 & 748 & 0 & 183 & 78 & 62 & 127 & 67 & 59 & 98 & 60 & 69 & 68 & 65 & 63 & 99 & 84 \\
\hline $\begin{array}{l}\text { Wetlands/Salt Pans to } \\
\text { Agriculture (Other) }\end{array}$ & 1.631051176 & 424.53 & 7609 & 2892 & 0 & 263 & 62 & 147 & 211 & 38 & 254 & 180 & 37 & 155 & 130 & 51 & 127 & 100 & 76 \\
\hline Wetlands/Salt Pans to Water & 1 & 89.01 & 1978 & 989 & 0 & 100 & 20 & 18 & 34 & 10 & 20 & 20 & 13 & 12 & 20 & 11 & 12 & 12 & 31 \\
\hline Water to Forest Deciduous & 3.181818182 & 9.45 & 138 & 33 & 0 & 14 & 3 & 2 & 6 & 6 & 3 & 2 & 4 & 2 & 1 & 2 & 1 & 2 & 2 \\
\hline Water to Forest Evergreen & 1.934235977 & 90 & 1517 & 517 & 0 & 153 & 29 & 55 & 48 & 21 & 41 & 29 & 24 & 26 & 14 & 21 & 12 & 17 & 10 \\
\hline Water to Scrub/Shrub & 6.339285714 & 223.65 & 2877 & 392 & 0 & 87 & 10 & 39 & 51 & 17 & 38 & 38 & 22 & 40 & 35 & 22 & 54 & 43 & 44 \\
\hline Water to Grassland & 7.795803067 & 1738.62 & 21796 & 2478 & 0 & 1049 & 328 & 942 & 828 & 348 & 579 & 551 & 321 & 505 & 434 & 330 & 504 & 351 & 401 \\
\hline $\begin{array}{l}\text { Water to Barren/Sparsely } \\
\text { Vegetated }\end{array}$ & 33.21066667 & 1120.86 & 12829 & 375 & 0 & 144 & 47 & 45 & 73 & 38 & 71 & 129 & 44 & 140 & 78 & 110 & 106 & 62 & 91 \\
\hline Water to Urban & 1.84 & 20.7 & 355 & 125 & 0 & 25 & 12 & 4 & 5 & 8 & 3 & 2 & 3 & 1 & 0 & 7 & 2 & 1 & 4 \\
\hline Water to Agriculture (Other) & 4.055555556 & 19.71 & 273 & 54 & 0 & 10 & 7 & 3 & 4 & 1 & 4 & 4 & 0 & 3 & 7 & 1 & 3 & 1 & 0 \\
\hline Water to Wetlands/Salt Pans & 17.88744138 & 3089.34 & 36245 & 1919 & 0 & 777 & 368 & 787 & 780 & 356 & 496 & 621 & 404 & 526 & 479 & 392 & 594 & 497 & 498 \\
\hline
\end{tabular}


Table 3. 2006-2011 Flood Frequency Impact on Land Cover, Summarized Table

\begin{tabular}{|c|c|c|c|c|c|c|c|c|c|c|c|c|c|c|c|c|c|c|c|}
\hline & & & & $\begin{array}{c}\text { Observed Water } \\
\text { Frequency \% }\end{array}$ & & & & & & & & & & & & & & & \\
\hline $\begin{array}{l}\text { Bivariate Change Classes } \\
2006-2011\end{array}$ & $\begin{array}{l}\text { Ratio of flood } \\
\text { pixels to } \\
\text { non-flood }\end{array}$ & Hectares & $\begin{array}{l}\text { Total } \\
\text { Pixels }\end{array}$ & $\mathbf{0}$ & 1 & 2 & 3 & 4 & 5 & 6 & 7 & 8 & 9 & $\#$ & \# & \# & \# & \# & \# \\
\hline $\begin{array}{l}\text { Forest Deciduous to } \\
\text { Water }\end{array}$ & 4.110465116 & 63.63 & 879 & 172 & 0 & 50 & 0 & 29 & 0 & 13 & 1 & 15 & 4 & 11 & 7 & 2 & 9 & 7 & 10 \\
\hline Forest Evergreen to Water & r 3.775700935 & 72.72 & 1022 & 214 & 0 & 45 & 0 & 28 & 1 & 29 & 1 & 24 & 9 & 13 & 5 & 12 & 19 & 12 & 8 \\
\hline Scrub/Shrub to Water & 6.383116883 & 88.47 & 1137 & 154 & 0 & 32 & 1 & 22 & 0 & 16 & 4 & 17 & 2 & 13 & 6 & 2 & 7 & 4 & 3 \\
\hline $\begin{array}{l}\text { Grassland to } \\
\text { Wetlands/Salt Pans }\end{array}$ & 1.114355231 & 41.22 & 869 & 411 & 0 & 52 & 0 & 31 & 0 & 46 & 3 & 23 & 7 & 6 & 7 & 5 & 3 & 2 & 9 \\
\hline Grassland to Water & 15.5 & 200.88 & 2376 & 144 & 0 & 51 & 1 & 36 & 0 & 21 & 4 & 23 & 7 & 21 & 11 & 17 & 14 & 13 & 10 \\
\hline $\begin{array}{l}\text { Barren Sparsely } \\
\text { Vegetated to Grassland } \\
\text { Barren Sparsely }\end{array}$ & 1.083832335 & 16.29 & 348 & 167 & 0 & 6 & 0 & 39 & 0 & 7 & 1 & 6 & 7 & 14 & 10 & 1 & 3 & 2 & 1 \\
\hline $\begin{array}{l}\text { Vegetated to } \\
\text { Wetlands/Salt Pans }\end{array}$ & 11 & 2.97 & 36 & 3 & 0 & 0 & 0 & 2 & 0 & 0 & 0 & 2 & 0 & 4 & 3 & 4 & 1 & 0 & 3 \\
\hline $\begin{array}{l}\text { Barren Sparsely } \\
\text { Vegetated to Water }\end{array}$ & 62.5 & 157.5 & 1778 & 28 & 0 & 14 & 0 & 5 & 0 & 6 & 1 & 4 & 5 & 1 & 6 & 3 & 3 & 1 & 5 \\
\hline $\begin{array}{l}\text { Agriculture (Other) to } \\
\text { Water }\end{array}$ & 9.676056338 & 185.49 & 2274 & 213 & 0 & 121 & 1 & 63 & 1 & 53 & 11 & 39 & 24 & 21 & 38 & 44 & 60 & 69 & 25 \\
\hline $\begin{array}{l}\text { Wetlands/Salt Pans to } \\
\text { Water }\end{array}$ & 3.576923077 & 8.37 & 119 & 26 & 0 & 8 & 0 & 3 & 0 & 5 & 0 & 1 & 1 & 1 & 2 & 2 & 2 & 2 & 1 \\
\hline $\begin{array}{l}\text { Water to Forest } \\
\text { Deciduous }\end{array}$ & 6.565217391 & 108.72 & 1392 & 184 & 0 & 47 & 1 & 26 & 1 & 23 & 0 & 14 & 8 & 7 & 9 & 7 & 13 & 11 & 13 \\
\hline Water to Forest Evergreen & 4.18630137 & 137.52 & 1893 & 365 & 0 & 50 & 1 & 40 & 0 & 22 & 2 & 16 & 6 & 15 & 15 & 5 & 10 & 1 & 8 \\
\hline Water to Scrub/Shrub & 11.61863354 & 841.77 & 10158 & 805 & 0 & 180 & 12 & 101 & 10 & 75 & 15 & 87 & 40 & 50 & 49 & 26 & 63 & 38 & 43 \\
\hline Water to Grassland & 4.88589398 & 489.42 & 6551 & 1113 & 0 & 248 & 1 & 155 & 4 & 125 & 10 & 127 & 56 & 83 & 84 & 58 & 74 & 49 & 75 \\
\hline $\begin{array}{l}\text { Water to Barren/Sparsely } \\
\text { Vegetated }\end{array}$ & 39.07619048 & 738.54 & 8416 & 210 & 0 & 40 & 2 & 31 & 4 & 28 & 4 & 16 & 14 & 17 & 27 & 10 & 30 & 7 & 29 \\
\hline Water to Urban & 1.935483871 & 16.2 & 273 & 93 & 0 & 20 & 0 & 15 & 0 & 5 & 0 & 3 & 1 & 3 & 0 & 2 & 0 & 5 & 1 \\
\hline $\begin{array}{l}\text { Water to Agriculture } \\
\text { (Other) }\end{array}$ & 3.071625344 & 100.35 & 1478 & 363 & 0 & 23 & 1 & 22 & 0 & 23 & 2 & 16 & 5 & 13 & 3 & 10 & 17 & 8 & 10 \\
\hline $\begin{array}{l}\text { Water to Wetlands/Salt } \\
\text { Pans }\end{array}$ & 13.2887538 & 393.48 & 4701 & 329 & 0 & 56 & 0 & 28 & 1 & 19 & 1 & 20 & 9 & 14 & 16 & 7 & 10 & 13 & 13 \\
\hline
\end{tabular}

Table 4. 2001-2011 Flood Frequency Impact on Land Cover, Summarized Table

\begin{tabular}{|c|c|c|c|c|c|c|c|c|c|c|c|c|c|c|c|c|c|c|c|}
\hline \multirow[b]{2}{*}{$\begin{array}{l}\text { Bivariate Change Classes } \\
\text { 2001-2011 }\end{array}$} & \multirow[b]{2}{*}{$\begin{array}{l}\text { Ratio of flood } \\
\text { pixels to } \\
\text { non-flood }\end{array}$} & \multirow[b]{2}{*}{ Hectares } & \multirow[b]{2}{*}{$\begin{array}{c}\text { Total } \\
\text { Pixels }\end{array}$} & \multicolumn{16}{|c|}{ Observed Water Frequency \% } \\
\hline & & & & $\mathbf{0}$ & 1 & 2 & 3 & 4 & 5 & 6 & 7 & 8 & 9 & 10 & 11 & 12 & 13 & 14 & 15 \\
\hline Forest Deciduous to Water & 3.53831418 & 166.23 & 2369 & 522 & 120 & 71 & 45 & 31 & 28 & 33 & 32 & 29 & 28 & 34 & 18 & 25 & 34 & 23 & 24 \\
\hline Forest Evergreen to Water & 3.86796117 & 179.28 & 2507 & 515 & 127 & 64 & 63 & 52 & 45 & 27 & 41 & 36 & 33 & 33 & 33 & 36 & 37 & 33 & 27 \\
\hline Scrub/Shrub to Water & 6.44267516 & 182.07 & 2337 & 314 & 84 & 53 & 22 & 29 & 19 & 21 & 19 & 15 & 10 & 29 & 24 & 23 & 22 & 23 & 27 \\
\hline Grassland to Water & 5.54545455 & 5.49 & 72 & 11 & 1 & 2 & 0 & 1 & 2 & 0 & 0 & 1 & 1 & 0 & 1 & 1 & 0 & 0 & 0 \\
\hline $\begin{array}{l}\text { Barren Sparsely Vegetated to } \\
\text { Forest Deciduous }\end{array}$ & 2.58974359 & 9.09 & 140 & 39 & 9 & 5 & 3 & 0 & 0 & 1 & 0 & 2 & 2 & 0 & 1 & 0 & 3 & 0 & 0 \\
\hline $\begin{array}{l}\text { Barren Sparsely Vegetated to } \\
\text { Scrub/Shrub }\end{array}$ & 7.34328358 & 44.28 & 559 & 67 & 21 & 21 & 10 & 8 & 14 & 8 & 14 & 25 & 13 & 10 & 14 & 22 & 24 & 16 & 23 \\
\hline $\begin{array}{l}\text { Barren Sparsely Vegetated to } \\
\text { Grassland }\end{array}$ & 10.106383 & 42.75 & 522 & 47 & 18 & 13 & 7 & 10 & 8 & 23 & 12 & 15 & 12 & 10 & 6 & 11 & 13 & 22 & 13 \\
\hline $\begin{array}{l}\text { Barren Sparsely Vegetated to } \\
\text { Agriculture (Other) }\end{array}$ & 1.10326087 & 18.27 & 387 & 184 & 32 & 8 & 7 & 7 & 3 & 6 & 3 & 3 & 3 & 3 & 2 & 3 & 6 & 5 & 5 \\
\hline $\begin{array}{l}\text { Barren Sparsely Vegetated to } \\
\text { Wetlands/Salt Pans }\end{array}$ & 31.5 & 51.03 & 585 & 18 & 36 & 9 & 10 & 11 & 25 & 17 & 12 & 19 & 21 & 18 & 29 & 17 & 27 & 21 & 23 \\
\hline $\begin{array}{l}\text { Barren Sparsely Vegetated to } \\
\text { Water }\end{array}$ & 43.2258065 & 120.6 & 1371 & 31 & 7 & 2 & 9 & 3 & 3 & 3 & 5 & 7 & 6 & 6 & 6 & 4 & 4 & 6 & 7 \\
\hline Agriculture (Other) to Water & 9.54065621 & 601.92 & 7389 & 701 & 215 & 133 & 105 & 98 & 77 & 126 & 190 & 127 & 109 & 104 & 87 & 82 & 92 & 76 & 87 \\
\hline $\begin{array}{l}\text { Wetlands/Salt Pans to } \\
\text { Barren/Sparsely Vegetated }\end{array}$ & 1.42990654 & 27.54 & 520 & 214 & 57 & 18 & 17 & 13 & 11 & 7 & 11 & 7 & 6 & 9 & 6 & 9 & 7 & 10 & 4 \\
\hline $\begin{array}{l}\text { Wetlands/Salt Pans to } \\
\text { Agriculture (Other) }\end{array}$ & 1.85881908 & 441.99 & 7553 & 2642 & 177 & 143 & 169 & 194 & 149 & 163 & 156 & 182 & 175 & 176 & 132 & 142 & 118 & 95 & 111 \\
\hline Wetlands/Salt Pans to Water & 728 & 18 & 1731 & 629 & 91 & 31 & 20 & 12 & 19 & 15 & 10 & 9 & 18 & 9 & 12 & 15 & 8 & 16 & 16 \\
\hline Water to Forest Deciduous & 14.2058824 & 130.41 & 1551 & 102 & 29 & 15 & 12 & 13 & 14 & 16 & 15 & 16 & 9 & 12 & 16 & 8 & 14 & 12 & 11 \\
\hline Water to Forest Evergreen & 4.4787234 & 265.23 & 3605 & 658 & 182 & 116 & 60 & 110 & 52 & 45 & 46 & 30 & 33 & 38 & 24 & 33 & 29 & 21 & 24 \\
\hline Water to Scrub/Shrub & 16.2553191 & 1237.68 & 14598 & 846 & 268 & 140 & 140 & 124 & 124 & 113 & 89 & 90 & 100 & 108 & 72 & 88 & 85 & 83 & 85 \\
\hline Water to Grassland & 7.66381236 & 1852.65 & 23271 & 2686 & 1174 & 1204 & 4874 & 823 & 652 & 629 & 555 & 515 & 463 & 533 & 389 & 441 & 450 & 379 & 398 \\
\hline $\begin{array}{l}\text { Water to Barren/Sparsely } \\
\text { Vegetated }\end{array}$ & 38.5321285 & 1727.01 & 19687 & 498 & 171 & 80 & 83 & 102 & 130 & 148 & 109 & 87 & 63 & 60 & 51 & 81 & 105 & 76 & 105 \\
\hline Water to Urban & 2.92307692 & 44.46 & 663 & 169 & 57 & 22 & 14 & 14 & 9 & 10 & 9 & 7 & 14 & 7 & 7 & 12 & 4 & 7 & 7 \\
\hline Water to Agriculture (Other) & 4.33544304 & 123.3 & 1686 & 316 & 70 & 25 & 16 & 19 & 12 & 12 & 12 & 14 & 12 & 11 & 16 & 18 & 10 & 11 & 9 \\
\hline Water to Wetlands/Salt Pans & 20.5403564 & 3527.19 & 41099 & 1908 & 844 & 1016 & 6838 & 790 & 679 & 711 & 619 & 708 & 708 & 691 & 590 & 556 & 522 & 427 & 457 \\
\hline
\end{tabular}


Table 5. 1992-2011 Flood Frequency Impact on Land Cover, Summarized Table

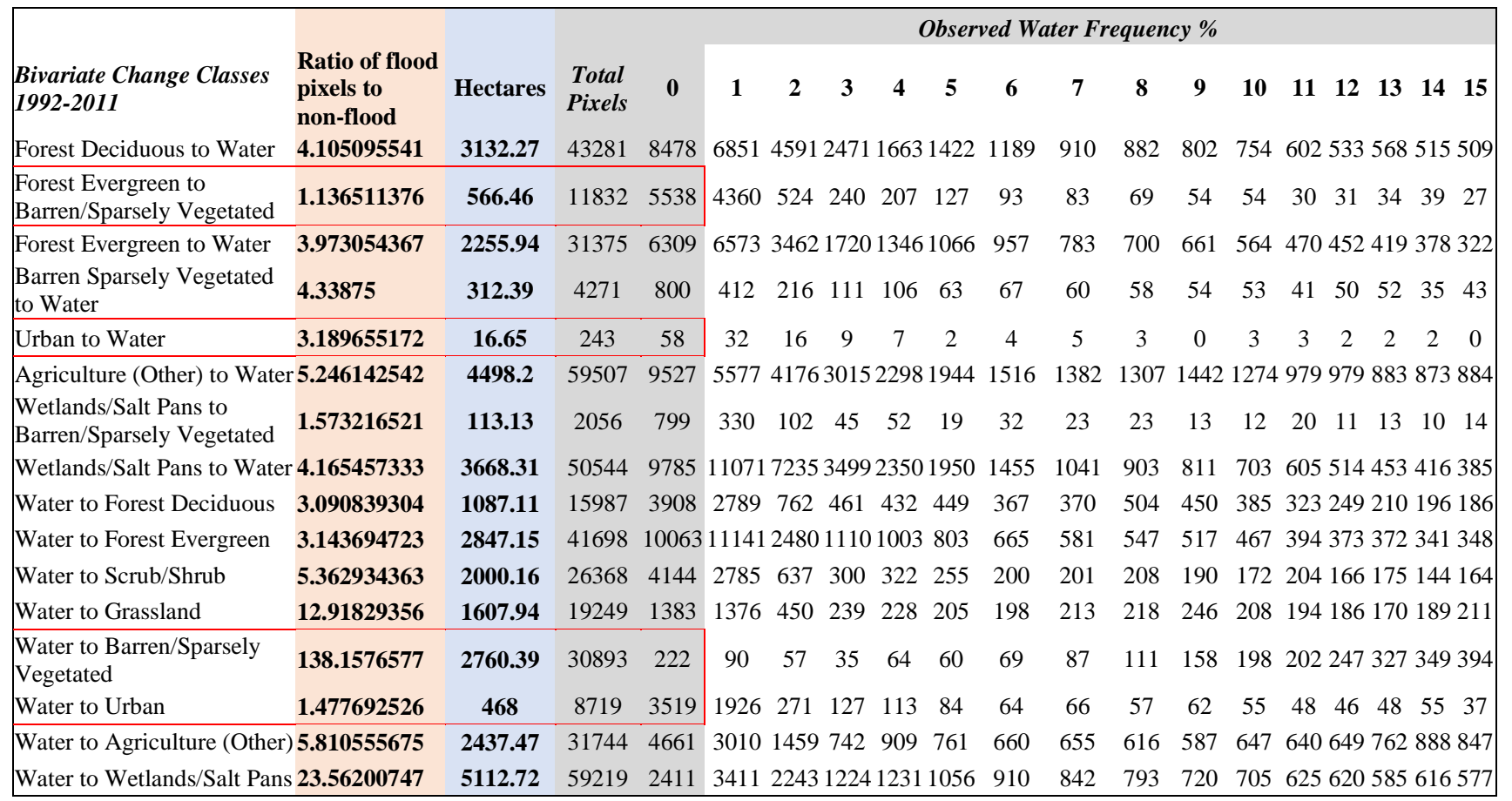

\section{Results and Discussions}

When analyzing the summarized tables, we discovered that land cover changes more often occurred within areas that had flooded (pixels that had a ratio $>1$ ); rather than, areas that had not flooded. These results are shown in Table 1. Water changing to Barren provided an indication of land that had flooded. Agriculture changing to barren suggested that frequent flooding may cause arable land to not be as productive. The urban to water change was a bit surprising and also important to note, even though it is a very small amount of change over the 2.5 million ha study area. Table 2 shows the results of the comparison of land cover change and flood frequency both between the years of 2001 and 2006. This time period also showed that Barren land cover change is highly correlated to flooding in this study area. When Barren land changes to vegetated cover and when Water changes to Barren, there is a strong likelihood that the change was due to flooding. For this date pair, we notice some previously called Water pixels have become Urban pixels. This change type occurred almost twice as often in areas that have flooded. This discovery was very interesting because it suggests that there is new Urban growth in flooded areas, albeit only about 21 ha. Table 3 shows similar results for the comparison of land cover change and flood frequency for the 2006-2011 date period. Barren changed to some classes, Water changed to Barren within the flood areas, and Water changed to Urban in a small area. This pattern continues for the date period 2001-2011. Table 4 depicts the results of the comparison of land cover change and flood frequency between the years of 2001 and 2011. Comparing the land cover change and flood frequency for the date pair 1992 and 2011, representing the entire time span confirmed that Barren land cover change is associated with flooding (Table 5). The results for this date pair also showed that almost 470 ha of Water turned to Urban.

After analyzing all the date pairs, we found that Urban land cover changes intersected with flood frequency regardless of the ratio. Table 6 shows the results of all Urban land cover change between 1992 and 2011 intersected with flood frequency regardless of the ratio. This table suggests, since the ratios are mainly very low, that most Urban change is not associated with flood. It also appears that lots of Evergreen Forest was harvested and replaced by Urban, but not in the flooded areas. To better understand this Urban land cover change, we compiled data to show Urban gains and losses within the flooded areas for date pair 1992-2011. Table 6 depicts the results of this comparison and shows that over 2600 ha of Urban were built within the areas that have flooded. This is much more substantial than the amount of Urban loss.

Table 6. Urban Gains and Losses in Frequently Flooded Areas, 1992 - 2011

\begin{tabular}{lccc}
\hline $\mathbf{1 9 9 2}$ - 2011 Urban Results & Acres & $\begin{array}{c}\text { Percent of Total Urban inside } \\
\text { frquently flooded areas }\end{array}$ & \begin{tabular}{c} 
Percent of Total Urban in the Study Area \\
\hline Urban loss inside areas that have flooded
\end{tabular} \\
Urban gain inside areas that have flooded & 208.89 & $85 \%$ & $0 \%$ \\
Urban no change in areas that have flooded & 4089.96 & $13 \%$ & $15 \%$ \\
Total Urban inside frequently flooded areas (2011) & 31194.36 & & $2 \%$ \\
Total Urban in the Study Area (2011) & 179615.7 & & \\
\hline
\end{tabular}


There was a substantial net gain in Barren features in each of the date pairs tested, and 2760 ha gain in Barren features over the entire study time period. Barren changed in flooded areas much more than it changed outside of the flooded areas. There was $~ 566$ ha of forest that changed to Barren land cover, which is more than happened outside the flooded areas. This is probably due to harvesting of trees in the flood plain, but could also be due to damage to forests by flooding. Nearly twice the amount of Agriculture was lost to Water ( 4500 ha) as was gained from Water (2437 ha) during the full study period. In every date pair, in flooded pixels, there was some Water which changed to Urban, usually around 16 ha, except between 2001 and 2011, when there was 44 ha of Urban growth. Over the entire study period, there was a loss of $\sim 17$ ha of Urban features to Water, but this was outweighed by the gain in Urban from Water (468 ha). The only Urban change that appears significantly due to flooding was Urban to Water or Water to Urban. According to this data, as of 2011, 85\% of the Urban features within the frequently flooding areas were built between 1992 and 2011.

Of course, some of the change identified in this analysis was invariably due to classification error. This is probably more acute in the 1992 dataset, which is less accurate than later datasets [9]. The NLCD accounts for most error in the other datasets by implementing a change-based land cover update approach. Starting from 2001, the USGS began implementing a method of land cover update whereby they re-classified only areas of change, thus increasing compatibility among the different years of the NLCD datasets for change analysis, and mitigating classification error as a factor [10,11]. This update approach results in the NLCD having a general accuracy of $80 \%$ overall and per class per pixel [12]. Any NLCD classification error for this study was likely limited to around 5-10\%.

Regardless of the potential classification error, this data indicates there are new urban features being constructed, and built within flooded areas.

\section{Conclusions}

The results of this analysis are very useful for identifying where these areas exist, how many areas, and the likelihood they are associated with flood. This has implications and applications to flood plain management and community land use planning. Demonstrating the accuracy of the flood identification methods from historical Landsat data, allowed us to analyze the flooded pixels against land cover, to better understand settlement patterns in relation to flood risk over time, as a proxy for local land use practices and planning. It provided both empirical data based on observation and quantifiable information on potential risk related to settlement patterns in a community. Combining this with the FEMA Special Flood Hazard Areas (SFHA) information and National Flood Insurance Program (NFIP) claims data would furnish floodplain managers with enhanced capacity to prioritize flood studies, investigate nontraditional flood prone areas, and inform more immediate and long term community mitigation and planning decisions.
There are many other ways to analyze the data from this study; our method was just one approach. The results of this study showed there is a relationship between some land cover change types and areas that frequently flood. It also indicated what change types of land cover change occurred. The Barren Class was the most impacted by flooding. Barren often changed to other vegetated categories in pixels that had flooded multiple times. Any gain in Urban land cover type, within the areas of frequent flooding, around the Red River should be investigated. This land use change indicates building in flood prone areas during the period of study. This study maps those locations. Pixels showing a loss of Urban should also be investigated to discern whether this is classification error or does it represent total destruction of urban structures from flooding. Since there were so few pixels, a number within margin of error, it could be just classification error.

Research of this nature should be done for many different geographic areas in order to understand the variability of flood frequency impact on land cover across the nation. It could also help ascertain if there are regional trends in impact. For example, the sources of flooding are different in coastal environments versus inland flood plain environments, so impact on land cover class change may be different. Other analyses could also be done using this data. We looked at any percent inundation $>0$, but maybe specific quantities of inundations correlate to specific land cover change. Additional research could be done to validate and quantify the accuracy of the study results, by tracking changes in the imagery with the flood data. More analysis could be done focusing only on Urban change in the frequently flooded areas for each of the date pairs to determine more precisely the range of dates of when new construction occurred.

\section{Acknowledgments}

We would like to acknowledge Flood APEX program within the Science and Technology Directorate of the U.S. Department of Homeland Security for supporting this research project. We would also like to acknowledge the USGS EROS Data Center for use and pre-processing of Landsat images and also for the USGS NLCD classification datasets.

\section{References}

[1] Pimenta, Matheus M., Fernando A.C. Cardoza, Rafael R. Ribeiro, and Andre C. Zingano (2016). Modern Environmental Science and Engineering, Vol. 2, No. 12, pp. 809-814. Academic Star Publishing Co.

[2] Skidmore, A.K., Bijker, W., Schmidt, K.S. and Kumar, L. (1997). Use of remote sensing and GIS for sustainable land management. In: ITC journal = bulletin de l'ITC, Vol. 3|4, pp. 302-315.

[3] aw A. Twumasi \& Edmund C. Merem (2007). "Management of Watersheds with Remote Sensing and GIS: A case study of River Niger delta Region in Nigeria”, International Journal of Environmental Research and Public Health, Vol.4, No. 2.

[4] Masek, J.G., Vermote, E.F., Saleous, N.E., Wolfe, R., Hall, F.G., Huemmrich, K.F., Gao, F., Kutler, J., and Lim, T.K. A Landsat Surface Reflectance Dataset for North America, 1990-2000. IEEE GEOSCIENCE AND REMOTE SENSING LETTERS, VOL. 3, NO. 1, JANUARY 2006. 
[5] Homer, C.H., Fry, J.A., and Barnes C.A. (2012). The National Land Cover Database, U.S. Geological Survey Fact Sheet 20123020, 4 p.

[6] Benke, Arthur and Colbert Cushing, editors. (2005). Rivers of North America. Elsevier Academic Press. pp. 1144.

[7] McPhee, John (February 23, 1987). "The Control of Nature: Atchafalaya". The New Yorker. Retrieved May 12, 2011. Republished in McPhee, John (1989). The Control of Nature. Farrar, Straus and Giroux.

[8] Brock, Eric J. (2008). Shreveport History. Greater Shreveport Chamber of Commerce. Archived from the original on Feb 19, 2008. Retrieved 06-10-2010.

[9] Stehman, S., Wickham, J., Smith, J. Yang, L, Thematic accuracy of the 1992 National Land-Cover Data for the eastern United States: Statistical methodology and regional results. Remote Sensing of Environment 86 (2003) 500-516.
[10] Homer, C.G., Dewitz, J.A., Yang, L., Jin, S., Danielson, P., Xian, G., Coulston, J., Herold, N.D., Wickham, J.D., and Megown, K., 2015, Completion of the 2011 National Land Cover Database for the conterminous United States-Representing a decade of land cover change information. Photogrammetric Engineering and Remote Sensing, v. 81, no. 5, p. 345-354.

[11] Xian, G, Homer, C, and Fry, J. 2009. Updating the 2001 National Land Cover Database land cover classification to 2006 by using Landsat imagery change detection methods. Remote Sensing of Environment, Vol. 113, No. 6. pp. 1133-1147.

[12] Wickham, J.D., Stehman, S.V., Gass, L., Dewitz, J., Fry, J.A., and Wade, T.G. Accuracy assessment of NLCD 2006 land cover and impervious surface. Remote Sensing of Environment, Volume 130, 15 March 2013, Pages 294-304. 